\title{
ANALYSIS OF PUBLIC SERVICE EFFICIENCY (SANITATION AGENCIES) IN SOUTH SULAWESI
}

\author{
Zaenudin \\ Fakultas Ekonomi Universitas Muslim Indonesia (UMI) \\ zaibtahman@yahoo.co.id
}

\begin{abstract}
The objective of this research is to know the relative efficiency of the sanitation service unit in each regency or municipality of South Sulawesi. The model for analysis is data envelopment analysis (DEA). The regions achieving efficiency for sanitation service during: (a) 2001 and 2002 were Makassar, Takalar and Maros, (b) for 2003 the region that achieved efficient for sanitation service are Makassar, Pare-pare, Barru, Bone, Takalar, Maros and Pinrang (c) in 2005 the region that achieved efficiency in sanitation service were Makassar, Bone, Maros and Pare-Pare, (d) in 2006 the region that achieved efficiency for sanitation service were Makassar, Bone and Maros.
\end{abstract}

Keyword: efficiency, sanitary public service agency

\section{INTRODUCTION}

Implementation of Act No.32 Year 2004 and Act No.33 Year 2004 have made fundamental changes on the arrangement of the relationship between central and local government, especially in the field of both governmental administration and in the financial relations. Both acts become a basis in determining policies related to local autonomy problems.

So far the root of problems is mistaken perception about autonomy. Autonomy is sometimes related to auto-money instead of services to communities. As a result, authority concept was more related to "finance" namely local rights to dig financial sources generated by the authority, not an authority to give services to communities. Because of the perception, authority struggles occurred between government levels with their own justifications so that community services will be neglected (Suwandi, 2002).

From the structural side of local government revenues there are some aspects having highly potential and substantial roles in contributing to the formation of local genuine revenues, one of them is local retribution. Local retribution, in its original language known as "user charge", is local charge as the payment of services or certain licences which were specially offered or given by local government for the sake of individuals or bodies (Siahaan, 2005: 432). So, in the case of local retribution, benefits from local retribution can be set directly. Retribution collection could be earned as a result of the utilization of public services offered or given by local government. Public services which were charged of their retribution were only types of public services having proper social economic judgements to become retibution objects.

According to above empiric and theoretical descriptions, it means that retribution is one of the local revenue sources having important roles on local revenue. In the retribution management we keep noting the retribution collection goals itself so that charges which exploited communities could not happened, means that burden given to communities was not comparable with services earned by communities. Retribution collection was compensation 
from the use of government services, thereore for-profit orientation was not allowed, because communities did not get benefits equal to costs $(M C=M B)$.

Dole, D (2004) explained that User Charges for public services could give effects on performance in providing public facilities, community welfare, and economical resources utilization. Research show that management improvement effort could generate increased revenues from User Charges (Bierhanzl and Dowing 1989, Bierhanzl 1999). Supplying public facilities become important things or important services, such as drinking water, public services, and health maintenance, so that User Charges influenced communities in utilizing public facilities and producing all goods and services.

According to above explanations, this research concentrated its focus on the management efficiency of public services agencies at ten Regencies/Municipalities in South Sulawesi. This research was different from other researches conducted by previous researchers in the field of efficiency and public services. The problems of this study focused on: (1) Does public services management (sanitation agency) at regencies/municipalities have relatively different efficiency levels; and (2) Which variables does have improvement chances (bacause of unoptimal use) in efforts to achieve efficiency at sanitation agency?

Empirically testing the public economy theory that discuss about the management efficiency of public goods and services affect the improvement of community welfare as a whole. Effciency theory approach was aimed to actualize a paradigm of managing efficient public goods and services.

\section{THEORETICAL STUDY}

\section{Management of Public Goods and Services by Government}

Developed countries prefer to deliver to private sector in supplying goods and services than government because government has many weaknesses in supplying goods and services which could be classified into four main groups: (1) alocation of economic sources; (2) efficiency in the use of economic sources; (3) stability and growth; and (4) revenue redistribution, as suggested by Due $(1985,7)$.

There are several reasons why government still interfere in economy: (1) because goods and services are not possible to be delivered to private sector because they are still very sensitive and strategic such as justice, national defence, policy making; (2) because of market failure, (3) goods and services generated by private provider have more costs than benefits such as roads and bridges.

In conclusion, the provision of public goods and services by government were not possible to deliver to private sector. The reasons were the costs of public gonds and services are higher than the benefits obtained by private provider. Besides that, the nature of public goods and services was devoted to public interests and regardless of who use them, so that at that condition the management of public goods and services must be supplied by government.

\section{Several Weaknesses in the Management of Public Goods and Services by Government}

The management of public goods and services always get sharp criticisms from various parties about management inefficiency conducted in providing public services to communities, for example, in the field of environment cleanliess such as garbages, management of traditional market, terminal management, health services and building permission service. This government activities, for some communities, were seen as still inefficient and even always facing failures in implementing policies made. This was resulted from some things, as suggested by Reksohadiprodjo $(2001,44)$ that government failures in implementing its 
programs because: (1) Government could not anticipate the consequences of policies made. Policies made always caused community reactions which was unsuitable with government hopes. For example, government give subsidies on fuel, but the rich get much benefits; (2) Government has a limited role in controlling policy consequences. For example, government controls the house rent prices for the poor in order for the poor could rent cheap houses. But developers divert their investments to other projects; (3) Government in making policies always have not enough abilities to implement them because its bureaucracy is unable; and (4) Naturally government give services to certain groups or certain vested interestd and may has self-interest, and always has conflict of interest.

Basic problems in the management of public goods and services were the presence of asymetrical information between community as the beneficiary of benefits and government as the provider of public goods and services. Asymetrical information could cause moral hazard to bureaucrats in the form of corruption and collusion related to the process of provision, auction and partner appointment in providing or managing public services. Government weaknesses in technology and financial sources of public services with various causes should be anticipated so that government must not necessarily do that, but deliver them to private sector as long as it still cooperate with private sector so that government only serves as a controlier and no more as a rower, as suggested by Obborne and Gaebler (1992) with their concept "Reinventing Government" in Mardiasmo $(2002,11)$.

\section{Economy Efficiency and Public Goods Provision}

Efficiency is related to the use of resources in fulfilling human needs or community needs at certain time concerned with costs and benefits in producing goods and services.

Efficiency focuses on allocation of goods and services after production. Efficiency in production is an important economic concept, but refused by studies of Bierhanzl and Downing 1988, Bierhanzl, 1999. Economically efficiency is related to user charges, but in practice, it is only efficiency in allocation (Dole, 2004).

Efficiency measures were stated indirectly by decision system model approach, namely a concept of economic welfare about efficiency from total systems efficiency. Total systems such as economy, government and organization were categorized as efficient if every reorganization could adds or increases value of a variable will reduce other variable values (Ferguson, 1991:1994 in Widodo, 2001:211). This efficiency concept could be applied to a system design which try to create the contets of decision making where government expenditure could be compared with government revenue. In other words, government programs could be made more efficient by paying more attention on measures, both on program inputs and program outputs, and making decisions of resources allocation among available program alternatives. Nevertheles, the concept of efficiency and effectiveness in decision system design approaches did not appear yet and still in the levels of collecting related data with efficiency measurement.

\section{RESEARCH METHODS}

Research was conducted in South Sulawesi at ten Regencies/Municipalities, namely Makassar City, Parepare City, Gowa Regency, Bone Regency, Palopo City, Barru Regency, Maros Regency, Pangkep Regèncy and Pinrang Regency.

input and output variables in operational approach were obtained from reports of public sevices agencies (the sanitation agencies). For the the sanitation agency, input variables include (i) labors, (ii) operational costs consisting of car number used, fuel and oil costs, (iii) equipment consisting of excavator, wheal leader, (iv) personnel costs consisting of salary, bonus and other allowances, (v) investment numbers, (vi) discretion. 
Data analysis technique used was non-parametric method, Data Envelopment Analysis (DEA). The formulation of DEA method could be seen at equations below. DEA analysis methods used were Charnes, Cooper, Rhoodes (CCR) versions.

Maximizing: $\mathrm{hj}=\frac{\sum_{r=1}^{s} u y_{n}}{\sum_{i=1}^{m} V_{i} x_{i}}$

Subject to: $\frac{\sum_{r=1}^{s} u_{r} y_{j}}{\sum_{i=1}^{m} V_{i} x_{j}} \leq 1 ; \mathrm{j}=1,2 \ldots \ldots, \mathrm{n}$

$\frac{u_{r}}{\sum_{i \mathrm{it}}^{m} V_{i} x_{b}}>\mathrm{e} ; \mathrm{r}=1, \ldots \ldots \ldots . \mathrm{s}$

$\frac{V_{i}}{\sum_{i=1}^{m} V_{i} x_{i}}>e ; r=1, \ldots \ldots . . . m>0$

This model evaluated relative performance of observed DMUs, every DMU gave variety of values from inputs producing $s$ outputs. Efficiency from $j^{\text {jh }} \mathrm{DMU}$, with the hij notation was measured by ratio index, where $i j$ are $i^{\text {st }}$ positive values of $j \mathrm{DMU}(i=1,2, \ldots \mathrm{m}), \mathrm{Y}_{j j}$ is output values of $r^{\text {th }}$ DMUj $(r=1,2, \ldots s)$.

DEA method was used in answering purposes about efficiency levels and improvement potentials for public services agency.

Then, DEA method was expressed in the form of objective function maximization from linear program as follows:

Objective function, $\max \theta=u_{1} y_{t_{0}}+\ldots+u_{s} y_{s o} \ldots .(2)$

Subject to $v_{1} x_{10}+\ldots+v_{m} x_{m o}=1$

$u_{1} y_{1 j}+\ldots+u_{s} y_{s j} £ \quad v_{1} x_{1 j}+\ldots+v_{m} x_{m j}$

$(j=1,2$, n) $v_{1}, v_{2}, \ldots \ldots . . v_{m}{ }^{3} 0$

$\mathrm{u}_{1}, \mathrm{u}_{2}$,

${ }^{3} 0$

Equation (2) through equation (6) were used in calculating the relative technical efficiency of public services agencies compared, where UKEo = public services agencies tested; UKEj = other public services agencies compared:

$\mathrm{n}=$ Numbers of public services agencies analyzed.

$m=$ Numbers of inputs used

$s=$ Numbers of output produced

$\mathrm{X}_{1 \mathrm{j}}=$ Numbers of input 1 used by the $\mathrm{j}$ public services agency

$Y_{1 j}=$ Numbers of output 1 produced by the j public services agency

$V_{1}=$ Weighted load of input 1

$V_{m}=$ Weighted load of input $m$

$U_{1}=$ Weighted load of output 1 . 
$\mathrm{U}_{\mathrm{s}}=$ Weighted load of output $\mathrm{s}$

$X_{10}=$ Numbers of input 1 used by public services agencies tested

$Y_{10}=$ Numbers of output 1 produced by public services agencies tested

$\theta=$ Values optimalized as indicators of relative efficiency from public services agencies tested.

A public services agency is said as efficient if it has $\theta=1$ and otherwise, is inefficient if it has $\theta<1$.

\section{RESEARCH RESULTS AND DISCUSSION}

\section{Efficiency of Sanitation Services in South Sulawesi}

By using calculation from DEA analysis method, it could be found the average scores of the efficiency of sanitation agencies per year. Sanitation services agencies showed that during period of 2001 through 2006, sanitation services at some regencies/municipalities in South Sulawesi showed various relative efficiency levels, as shown in Table 1 below.

In Table 1 it could be seen that efficiency levels at every regencies/municipalities in South Sulawesi was diverse, from the lowest facing Palopo Regency in year 2002 (17.21 percent) through the highest (100 persen) facing some regions of this research locations.

Table 1. Efficiency Levels of Sanitation Services at Some Selected Regencies/

Municipalities in South Sulawesi, 2001-2006 (\%)

\begin{tabular}{|l|c|c|c|c|c|c|}
\hline \multirow{2}{*}{$\begin{array}{l}\text { Name of } \\
\text { Sanitation }\end{array}$} & \multicolumn{6}{|c|}{ Year } \\
\cline { 2 - 7 } Agencies & 2001 & 2002 & 2003 & 2004 & 2005 & 2006 \\
\hline Makassar & 100 & 100 & 100 & 100 & 100 & 100 \\
Pare-Pare & 79.38 & 91.74 & 100 & 68.15 & 100 & 93.18 \\
Palopo & 18.50 & 17.21 & 60.86 & 27.49 & 21.97 & 35.79 \\
Barru & 35.82 & 37.14 & 100 & 44.06 & 38.72 & 64.51 \\
Bone & 53.67 & 53.44 & 100 & 53.04 & 100 & 100 \\
Gowa & 47.51 & 40.38 & 46.87 & 45.50 & 48.56 & 62.20 \\
Takalar & 100 & 100 & 100 & 100 & 71.52 & 75.15 \\
Maros & 100 & 100 & 100 & 100 & 100 & 100 \\
Pangkep & 40.87 & 34.12 & 45.96 & 52.96 & 51.80 & 28.60 \\
Pinrang & 30.44 & 25.06 & 100 & 39.32 & 77.99 & 66.64 \\
\hline Rata-rata & $\mathbf{6 0 . 6 1}$ & $\mathbf{5 9 . 9 0}$ & $\mathbf{8 5 . 3 6}$ & $\mathbf{6 3 . 0 5}$ & $\mathbf{7 1 . 0 4}$ & $\mathbf{7 2 . 5 9}$ \\
\hline
\end{tabular}

Source: Data were processed from DEA

It could be seen that efficiency levels at every regency/municipality in South Sulawesi were very diverse, from the lowest achieved by Palopo Regency in year 2002 (17.21 percent) through the highest (100 percent) achieved by some regions of this research locations (see Table 1).

In data of Table 1 it could be explained that from the period 2001 through 2006, the best performance score was achieved by three agencies, namely Makassar City Sanitation Agency, Takalar Sanitation Agency, and Maros Sanitation Agency where they got 100 persent score. While other Sanitation Agencies, the results showed varied difference, some sanitation agencies become better (namely Bone Sanitation Agency, Gowa Sanitation Agency, and Pare-Pare Sanitation Agency) and also some sanitation agencies fluctuated. 
In this research it was found that not only Makassar Sanitation Agency having efficiency level of $100 \%$ but there were three regencies/municipalities (sanitation services agencies) in 2001 showing the best performance or having efficiency level of $100 \%$ namely Makassar Sanitation Agency, Takalar Sanitation Agency and Maros Sanitation Agency.

In using. Data Envelopment Analysis (DEA) approach, public services agency (sanitation) having efficiency level of $100 \%$ more than once was possible. Then, in year 2002 there were two agencies showing the best performance namely Makassar Sanitation Agency and Takalar Sanitation Agency. Then, in year 2003 the results did not change significantly because there were seven efficient agencies namely Makassar Sanitation Agency, Pare-Pare Sanitation Agency, Barru Sanitation Agency, Bone Sanitation Agency, Takalar Sanitation Agency, Maros Sanitation Agency and Pinrang Sanitation Agency still recorded as the most efficient region. In year 2004 change happenned where the efficiency of sanitation services for Makassar Sanitation Agency, Takalar Sanitation Agency and Maros Sanitation Agency were identified as efficient. Furthermore, in year 2005 the efficiency of sanitation services for Makassar Sanitation Agency, Pare-Pare Sanitation Agency, Bone Sanitation Agency and Maros Sanitation Agency seen as the most efficient, then in year 2006 Makassar Sanitation Agency, Bone Sanitation Agency and Maros Sanitation Agency were seen as the most efficient.

\section{Finding/Knowing Efficiency Sources}

DEA analysis not only provide efficiency value for each Decision Making Unit (DMU) of sanitation agencies studied but also provide efficiency achievement target values of every input and output variables used. Besides that, in order to know the extent to which a compared sanitation agency generate a certain efficiency score, and which variables contribute significantly to the efficiency scores, it is important to calculate input and output proportion of sanitation services agencies to overall input-output numbers of regency/ municipality sanitation agencies.

Furthermore, Barru Sanitation Agency showed efficiency score of $40.38 \%$. The clear details could be seen in Table 2 .

Table 2. Target for Efficiency of Barru Unit, Year 2002

Efficiency Value of $40.38 \%$

\begin{tabular}{|c|c|c|c|c|}
\hline Variable & Actual & Target (Ideal) & $\begin{array}{c}\text { Improvement } \\
(\%)\end{array}$ & $\begin{array}{c}\text { Realization } \\
(\%)\end{array}$ \\
\hline Labor & 40 Persons & 14.3 Persons & 64.2 & 35.8 \\
\hline Vehicle Numbers & 4 Units & 1.4 Units & 64,2 & 35.8 \\
\hline Personnel Costs & Rp. $221,000,000$ & Rp. $38,493,245$ & 82.6 & 17.4 \\
\hline Operational Costs & Rp. $175,300,000$ & Rp. $55,652,021$ & 68.3 & 31.7 \\
\hline Investment & Rp. $100,000,000$ & Rp. $10,003,299$ & 90.0 & 10.0 \\
\hline Discretion & Rp. $7,200,000$ & 699,160 & 90.3 & 9.7 \\
\hline Waste Volume & $18,399.6 \mathrm{M}^{3}$ & $24,519.6 \mathrm{M}^{3}$ & 25.0 & 75.0 \\
\hline
\end{tabular}

Source: Data from DEA

Table 2 showed that the inefficiency source of Barru Sanitation Agency was labor used for workers in sanitation services numbering to 40 persons. But the target/ideal number was 14 persons so that there was excess of $64.2 \%$ or the realization was only $35.8 \%$. Vehicle numbers used were 4 units. But the target number was only 1 unit, so that there was excess of $64,2 \%$. 
Personnel costs consisting of wage/honorarium, the realization was $17.4 \%$. Operational costs consisting of maintenance cost of transportation vehicle, fuel, spare parts, tires, and so on, there were excessive target of $68.3 \%$. Investment in buying land for Final Discharge Ground location, the excessive target capacity was $90 \%$, and last for discretion in the case of buying office inventory goods, the excessive target capacity was $90.3 \%$.

For clear details of inefficient agencies in year 2003, it could be seen in Table 3 . The table show ineficiency of Palopo Sanitation Agency with efficiency score of $60.86 \%$.

Table 3. Target for Efficiency of Palopo Unit, Year 2003

Efficiency of $60.86 \%$

\begin{tabular}{|l|r|r|r|r|}
\hline \multicolumn{1}{|c|}{ Variable } & \multicolumn{1}{c|}{ Actual } & Target (Ideal) & $\begin{array}{c}\text { Improvement } \\
(\%)\end{array}$ & $\begin{array}{c}\text { Realization } \\
(\%)\end{array}$ \\
\hline Labor & 120 Persons & 49.7 Persons & 58.6 & 41.4 \\
\hline Vehicle Numbers & 27 Units & 5.0 Units & 81.6 & 18.4 \\
\hline Personnel Costs & Rp.648,000,000.0 & Rp.244,819,279 & 62.2 & 37.8 \\
\hdashline Operational Costs & Rp.575,379,310.0 & Rp.164,156,646 & 71.5 & 28.5 \\
\hline Investment & Rp. $40,300,000$ & Rp. $24,525,975$ & 39.1 & 60.9 \\
\hline Discretion & Rp. $11,250,000$ & Rp. $6,846,591$. & 39.1 & 60.9 \\
\hline Waste Volume & $38,023.2 \mathrm{M}^{3}$ & $44,863.2 \mathrm{M}^{3}$ & 15.3 & 84.7 \\
\hline
\end{tabular}

Source: Data were processed from DEA

Table 3 show that inefficiency of Palopo Sanitation Agency was due to variables used exceed the stated targets such as labors, drivers, park workers, street sweepers and drainage cleaners numbering to 120 persons, while the target (ideal) number was only 50 persons so that there was inefficiency excess of $58.6 \%$. Besides that, vehicle numbers used were 27 units but the target number was only 5 units. Personnel costs consisting wages and labors exceed the target of $62.2 \%$. Furthermore, operational costs consisting of reparation and spare parts replacement, service cost, fuel and lubricant purchase exceed the ideal fund namely $71.5 \%$ Investment consisting of capital expenditure for procurement of land facilities for Final Discharge Ground also exceed the target of $39.1 \%$ and waste volume that could be transported was $84.7 \%$.

Ineeficiency of each Sanitation Agencies in year 2004 could be seen in Table 4.

Table 4. Target for Efficiency of Pare-Pare Unit, Year 2004

Efficiency Value of $68.15 \%$

\begin{tabular}{|c|c|c|c|c|}
\hline Variable & Actual & Target (Ideal) & $\begin{array}{c}\text { improvement } \\
(\%)\end{array}$ & $\begin{array}{c}\text { Realization } \\
(\%)\end{array}$ \\
\hline Labor & 186 Persons & 126.8 Persons & 31.8 & 68.2 \\
\hline Vehicle Number & 35 Units & 22.0 Units & 37.1 & 62.9 \\
\hline Personnel Costs & Rp. $827,110,000$ & Rp. $359,872,729$ & 56.62 & 43.38 \\
\hline Operational Costs & Rp. $769,662,000$ & Rp. $524,525,740$ & 31.8 & 68.2 \\
\hline Investment & Rp. $210,000,000$ & Rp. $143,115,296$ & 31.8 & 68.2 \\
\hline Discretion & Rp. $\quad 11,925,000$ & Rp. $\quad 7,563,970$ & 36.6 & 63.4 \\
\hline Waste Volume & $159,840 \mathrm{M}^{3}$ & $164,160 \mathrm{M}^{3}$ & 2.7 & 97.3 \\
\hline
\end{tabular}

Source: Data were processed from DEA 
According to Table 4 it is shown that inefficiency of Pare-Pare Sanitation Agency was due to labor used was 186 persons, but the target was only 127 persons, so that there was excess of $31.8 \%$. Vehicle numbers used was 35 units while the target number was only 22 units so that there was inefficiency of $37.1 \%$. Personnel costs consisting of wage for waste workers also exceed the target (ideal) of $56.62 \%$. Operational costs consisting of the purchase of fuel, spare parts replacement, tires and so on used great amount fund which exceed the ideal of $31.8 \%$. Investment in the form of the capital expenditure of heavy equipment such as excavator and motor land transporter exceed the stated target of $31.8 \%$. Discretion in this case was leader authority in making policies or decisions to buy goods or office inventories such as the purchase of computer ecxeed the ideal amount. Efforts that could be done in order to become efficient was to reduce cost of $36.6 \%$. Waste volume transported was $159,840 \mathrm{M}^{3}$.

Furthermore, the causes of inefficiency of Pinrang Sanitation Agency with inefficiency level of $77.99 \%$ could be seen in Table 5 below.

Table 5. Target for Efficiency of Pinrang Unit, Year 2005

Efficiency Value of $77.99 \%$

\begin{tabular}{|c|c|c|c|c|}
\hline Variable & Actual & Target (Ideal) & $\begin{array}{c}\text { Improvement } \\
\text { (\%) }\end{array}$ & $\begin{array}{c}\text { Realization } \\
(\%)\end{array}$ \\
\hline Labor & 153 Persons & 39.1 Persons & 74.4 & 25.6 \\
\hline Vehicle Numbers & 18 Units & 4.3 Units & 76.3 & 23.7 \\
\hline Personnel Costs & Rp. $719,800,000$ & Rp. $120,834,829$ & 83.2 & 16.8 \\
\hline Operational Costs & Rp. $182,500,000$ & Rp.142,325,476 & 22.0 & 78.0 \\
\hline Investment & Rp. $385,000,000$ & Rp. $13,140,199$ & 96.6 & 3.4 \\
\hline Discretion & Rp. $13,613,000$ & Rp. $\quad 4,803,484$ & 64.7 & 35.3 \\
\hline Retribution Revenues & $45,360 \mathrm{M}^{3}$ & $73,800 \mathrm{M}^{3}$ & 61.4 & 38.6 \\
\hline
\end{tabular}

Source: Data from DEA

According to Table 5 it could be seen that inefficiency of Pinrang Sanitation Agency was due to labors used were 153 persons while the ideal number was 39 persons so that there was excess of $74.4 \%$. vehicle numbers used were 18 units while the ideal number was 4 units. Personnel costs consisting of wage for waste workers/labors, car drivers, street sweeper, and drainage cleaners.. costs were great enough so that exceed the target where the excess was $83.2 \%$. Furthermore, operational costs in this case consisting of vehicle maintenance costs, fuel/lubricant, spare parts, car tires, 1 motor vehicle license, accumulator so that the excess was $22 \%$. Investment consisting of the purchase of garbage pickup car, the provision of container amounted to Rp.385,000,000 but the ideal cost was only Rp.13,140,199 so that the inefficiency was $96,6 \%$. Then, discretion which was government authority in making policies to buy office equipment such as filling cabinet, fans, tables and chairs used budget capacity of Rp. $13,613,000$. But the target was Rp. 4,803,484, so in this case the inefficiency was $64.75 \%$.

Pangkep Sanitation Agency has achieved efficiency level of 17.08. This value was considered as inefficient in year 2006 because it did not achieve 100 percent. The ineeficiency causes could be seen in Table 6 below. 
Table 6. Target for Efficiency of Pangkep Unit, Year 2006

Eficiency value of $28.60 \%$

\begin{tabular}{|c|c|c|c|c|}
\hline Variable & Actual & Target/deal & $\begin{array}{l}\text { Improvement } \\
(\%)\end{array}$ & $\begin{array}{c}\text { Realization } \\
(\%)\end{array}$ \\
\hline Labor & 65 Persons & 18.6 Persons & 71.4 & 28.6 \\
\hline Vehicle Number & 11 Units & 2.9 Units & 73.5 & 26.5 \\
\hline Personnel Costs & Rp. $\quad 501,600,000$ & Rp. $91,269,749$ & 81.8 & 18.2 \\
\hline Operational Costs & Rp. $\quad 692,165,000$ & Rp. $197,964,541$ & 71.4 & 28.6 \\
\hline Investment & Rp. $2,456,301,250$ & Rp. $101,950,663$ & 95.8 & 4.2 \\
\hline Discretion & Rp. $124,000,000$ & $\operatorname{Rp} \quad 2,759,663$ & 97.8 & 2.2 \\
\hline Waste Volume & $31,320 \mathrm{M}^{3}$ & $36,000 \mathrm{M}^{3}$ & 13.0 & 8.7 \\
\hline
\end{tabular}

Source: Data were processed from DEA

In Table 6 it is seen that the inefficiency causes of Pangkep Sanitation Agency were labor numbers used in this case as garbage workers/labors, street sweeper, car drivers and drainage cleaners numbering to 65 persons but the ideal number was 19 persons $(18.6 \%)$. Vehicle numbers used for transporting wastes were 11 units, but the ideal number was only 3 units. Personnel costs consisting of wages for workers also exceed the ideal number. The excess was 81.8 percent. Furthermore, operational costs in this case consisting of the purchase of fuel, oil/lubricant, motor vehicle license, vehicle repair amounting to $R p$ $692,165,000,-$, but the ideal amount was Rp $197,964,541$ or the inefficiency was 71.4 percent. Investment consisting of purchase of land motor vehicle, purchase of lawn mower, purchase of heavy equipment, purchase of machined and non-machined workshop, this costs exceed the real capacity of 77.4 percent.

\section{Improvement Efforts for Ineeficient Sanitation Agencies}

If the previous description explained about distribution of potential improvement levels for each input/output, this section will discuss efforts should be done by each inefficient Sanitation Agency according to its reference. Which Sanitation Agency should be made as efficient reference set by inefficient sanitation agencies was shown in Table 7 .

In Table 7 it is shown that all inefficient sanitation agencies have references but sanitation agencies having efficiency score of 100 percent were Makassar Sanitation Agency, Maros Sanitation Agency and Pare-Pare Sanitation Agency in year 2003 and 2005, Bone Sanitation Agency in year 2003, 2005 and 2006, Takalar Sanitation Agency in year 2001 through 2004, and Pinrang Sanitation Agency in year 2003. 
Table 7. Efficient Reference Set of-Sanitation Agencies of Regencies/Municipalities in South Sulawesi, 2001-2006

\begin{tabular}{|l|l|l|l|l|c|l|}
\hline \multirow{2}{*}{$\begin{array}{l}\text { Agency } \\
\text { Name }\end{array}$} & \multicolumn{6}{|c|}{ The Sanitation Agencies of Regencies/Municipalities } \\
Efficient Reference Set, Year
\end{tabular}

Source: Data (processed), 2007

According to their references, inefficient sanitation agencies could take efficiency improvement efforts. Information contained in previous Table (Table 1) could be used as criteria for making the improvement. Then, explanation about thirgs which need attentions from inefficient sanitation agencies: consistently, Makassar Sanitation Agency, Takalar Sanitation Agency and Maros Sanitation Agency become reference for Pare-Pare Sanitation Agency in year 2001 and so did in year 2002 and 2004. The efficency level of the sanitation agencies in year 2001 was 78.38 percent, in year 2002 the efficency level was 91.74 percent and in year 2003 and 2005 they achieved the efficency level of 100 percent. In year 2004 the efficency level was 68.15 percent and in year 2006 the efficency level was 93.18 percent.

Palopo City Sanitation Agency in year 2001 and 2002 have two references, namely Makassar Sanitation Agency and Maros Sanitation Agency. But in year 2003, its references were Barru Sanitation Agency and Maros Sanitation Agency. In year 2004 its references were Makassar Sanitation Agency and Takalar Sanitation Agency, then, in year 2005 its references were Makassar Sanitation Agency, Pare-Pare Sanitation Agency and Maros Sanitation Agency. Actually Palopo Sanitation Agency could improve its efficiency by giving attention to some inputs such as labors, investment, operational costs and discretion. Furthermore, improvement at output side also must be main priority because Palopo Sanitation Agency could give services of transporting wastes where the average waste volume transported in year 2001, 2002, and 2006 was 87 percent. 


\section{PREVIOUS RESEARCHES - RELATING TO EFFICIENCY OF PUBLIC - SERVICES MANAGEMENT}

Jong, et al., (1999) conducted research in the field of environment with research focus on the inefficiency of environmental sanitation services (wastes) in Netherland. The research results showed that the use of higher subsidy could affect efficiency increase or could cause inefficiency. If public utilities handling wastes minimize the sanitation control, then budget for generating services also could be reduced to the lowest level, while investments which have been done become excessive so that they caused inefficiency. Otherwise, if public utilities handling wastes want to improve sanitation services, they should increase subsidy for operational costs so that investments which have been done become efficient and will affect the efficiency of sanitation management.

One of the sources of inefficiency of public services management was due to leaders of public services management could not determine how much profits should be achieved, this case was different with private enterprises which could maximize profits by adjusting to cost levels with their revenues. In other side, public utilities could not freely change the amount of budgets because they will change the size of budget in its activity. The presence of tight procedures facing public utilities in changing its budget was one of the constraints in determining target achievement (Neskanen 1971, in Bierhanzl, Dowing: 1998).

This research results were related to the efficiency of sanitation management at ten Regencies/Municipalities in research areas, it was found that there were only four research areas which were efficient in managing sanitation and the rest were six inefficient Regencies/ Municipalities. Factors influencing inefficiency of sanitation management at several areas were: (1) operational costs, (2) personnel costs, (3) investment costs, (4) vehicle numbers, and (5) discretion.

\section{CONCLUSION}

This research used Data Envelopment Analysis (DEA). This research could explain efficiency performance levels. The efficiency of performance levels could be seen from services agencies which have achieved 100 percent efficiency levels, and which were inefficient so that sanitation agencies which have achieved 100 percent efficiency levels should be maintained, while sanitation agencies which have not achieved 100 percent efficiency levels should get attention and better sanitation management in order to improve its efficiency levels.

Some regions which were identified as efficient during period: (a) year 2001 and 2002 were Makassar, Takalar, and Maros, (b) year 2003 were Makassar, Pare-Pare, Barru, Bone, Takalar and Maros, (c) year 2005 were Makassar, Bone, Pare-Pare and Maros, and (d) year 2006, the efficient regencies were the Makassar, Bone and Maros. The causes of inefficient regions were due to: (1) Inefficient use of operational costs; (2) The presence of disretion factor; (3) The budget limitations were the usual reasons of limited performance in handling sanitation problems; (4) Lack of efforts to change practices in efficiency become indication; and (5) Lack of government commitment in sanitation services.

It is expected for government to review and re-evaluate retribution tariff of proper sanitation services, because prevailing tariffs were still below the ideal price levels compared with the community purchasing power abilities.

The limitation of this research was due to it used DEA model having change dynamics in that efficiency levels will change any time when there are new Sanitation Service Agencies which are added in research samples where they have better efficiency than previous samples of sanitation service agencies or when input and output compositions have changed. 
UNISIA, Vol. XXXIV No. 76 Januari 2012

Research implication for the sanitation service agencies which have less 100 percent efficiency, they could increase their efficiency by adjusting inefficient input and output to the target for unit efficiency. It is hoped that these research results could give information to Local Government, in this case, head of sanitation service agency about the efficiency of the management of local revenues in increasing services and welfare of local communities.

\section{BIBLIOGRAPHIES}

Ananda F. Candra (2002). "Problem of the Implementation of Fiscal Decentralization in Regional Autonomy: The Case of Malang Municipality and Trenggalek Distric". Facuity of Economics Brawijaya-USAID. (Data internet 2005)

Andenrberg, Dan, et al. (2006). Time, Self-Selection And User Charges For Public Goods. Internet- Proquest, Januari 2006. E-mail: D.Anderberg@warwick.ac.uk

Asenso-Okyere, WK, et al, (1998). Cost Recovery in Ghana: Are There Any Changes in Health Care Seeking Behaviour. Institute of Statistical, Social and Economic Research (ISSER), University of Ghana, Legon, Ghana.

Bails, Dale and Margie A. Tieslau (1999). The Impact Of Fiscal Costitution On State And Local Expenditures. dbails@cbu.edu

Bierhanzl, E,J, and P.B. Downing (1998). "Incentives for Efficiency, User Changers and Municipal Spending" Journal of Public Finance and Public Choice.

Borge, Lars-Erik dan Rattso, Jorn (2004). The Relations Ships Between Cost and User Charges: The Case of Norwegian. University of Science and Technology. N-7491 Trondheim, Norway.

Caballero, Ricardo. J and Arvind Krishnamurthy (2004). "Fiscal Policy And Financial Depth". Working Paper 04-22 May" 3, 2004. http://ssrn.com/abstract=548384.

Cooper, W, Lawrence M. Seiford, Kaoru Tone (2000). Data Envelopment Analysis: A Comprehensive Text With Models, Aplications, References and DEA-Solver Sofware. Kluwer Academic Publisher.

Devas, Nick, et.al. (1989). Keuangan Pemerintah Daerah Di Indonesia. Jakarta: Penerbit Universitas Indonesia UI-Press.

Due dan Friedlaender (1983). Keuangan Negara Perekonomian Sektor Publik. Jakarta: Penerbit Erlangga.

Fattah, Sulaeman (2002). "Kompleksitas Otonomi Daerah Di Indonesia: Telaah Terhadap Antisipasi Konseptual, Politik dan Budaya". Jurnal Administrasi Negara. Vol. Il No 02 April

Firdaus. Riza. M. (2002). "Pengukuran Efisiensi Harga Dengan Metode Data Envelopment Analysis (DEA) Sebagai Pertimbangan Dalam Menentukan Positioning Harga". Thesis Magister Program Pascasarjana Universitas Brawijaya Kehususan Manajemen Pemasaran. 
Analysis of Public Service Efficiency (Zaenudin)

Fisher, Ronald (1996). State And Local Public Finance. Printed in the United State of America.

Favero, Carlo and Tommaso Manacelli (2005). Fiscal Policy Rule and Regime (in) Stability: Evidence From the USA. Working Paper. http://www.igier.uni-bocconi.it

Hagiu, Andrei. "Two-Sided Platforms: Pricing and Social Efficiency - Extensions". Research Institute of the Economy Trade and Industry and Princeton University; andrei-hagiu@rieti. go.jp.

Hyman David, N. (1993). Public Finance A.Contemporary Application of Theory to Policy (Fourth Edition), Boston: Irwin

Ismail, Munawar. et. al. (2006). "Efisiensi Relatif Kantor Pelayanan Pajak Bumi dan Bangunan (KP PBB) di Jawa Timur" (Studi pada 10 KP PBB).

Jong, Roelof De Roeloy et. al. (2000). "Inefficiencies in Publik Environmental Services." in Environmental and Resource Economics; May 2000; 16, 1; ABI/INFORM Research pg.69

Kaho, Josef Riwu (1997). Prospek Otonomi Daerah di Negara Republik Indonesia Identifikasi Beberapa Faktor Yang Mempengaruhi Penyelenggaraannya (1st Ed.) Jakarta: Penerbit Rajawali Pers.

Kirana, Wihana, et al. (2000). Kajian Profil Daerah Tingkat II Ditinjau Dari Aspek Potensi Penerimaan Daerah, Yogyakarta: PAU Studi Ekonomi UGM.

K. J. Davey. (1988). Financing Regional Government. 1983 First Edition. Jhon Wiley and Sons. Press. (Amanulla dkk, Penterjemah) 1988. Pembiayaan Pemerintah Daerah Edisi Pertama. Penerbit UI-Press.

Lira, Ricardo (1994). "Pension Fund and Hausing Finance in Chile: A Question of Social Efficiency". Journal of Haousing Research Volume 5. Issue 2. pg 229-245.

Lin Crase and Brain Dollery. (2005) A Critical Note on Local Government Charges in Australia: Have we Lost sight of how to fund public and merid goods.

Loehr William dan Rosario Manasan (1999). "Fiscal Decentralization and Economic Efficiency: Measurement and Evaluation". Discussion Paper No. 38.

Makmun (2002). "Efisiensi Kinerja Asuransi Pemerintah". Kajian Ekonomi dan Keuangan , Vol,6, No.1 (data internet 2002).

Mangkoesoebroto, Guritno (1991). Ekonomi Publik (Edisi Keempat), Yogjakarta: BPFE UGM

Mubyarto (2000). "Otonomi Darah Dan Prospek Ekonomi Dan Keuangannya Di Tiga Daerah Tingkat II: Sleman, Sukohardjo, Bandar Lampung". Laporan Penelitian Disampaikan Pada Pertemuan Forum II-FPPM, 3-4'Mei 2000, di Yoyakarta. Data internet 2005.

(2001). Prospek Otonomi Daerah Dan Perekonomian Indonesia, Yogyakarta: BPFE-UGM.

Muliaman D, Hadad. et al. (2003). "Pendekatan Parametrik Untuk Efisiensi Perbankan Indonesia".,(data internet 2003) 
UNISIA, Vol. XXXIV No. 76 Januari 2012

Mardiasmo (2002). "Otonomi Daerah Sebagai Upaya Memperkokoh Basis Perekonomian Daerah". Jurnal Artikel Tahun I No 4 Juni 2002 (data internet 2004).

Musgrave, Richard. A, Feggy B Musgrave (1993). Keuangan Negara Dalam Teori dan Praktek (Edisi Kelima). Jakarta: Penerbit Erlangga.

M. Suparmoko (1987). Keuangan Negara Dalam Teori dan Praktek. Yogyakarta: BPFE Yogyakarta.

Pribadi, Krishna Nur. "Tingkat Efisiensi Wilayah Kabupaten dan Kota Dalam Industri Manufaktur di Jawa Barat Tahun 1987, 1992 dan 1997", (Sumber Internet Juni 2006).

Purwantoro, R. Nugroho (2003). "Penerapan Data Emvelopment Analysis (DEA) Dalam Kasus Pemilihan Produk Inkjet Personal Printer". Usahawan No. 10. TH XXXII Oktober 2003.

Reksohadiprodjo, Sukanto (2001). Ekonomika Publik (Edisi Pertama). Yogyakarta: Penerbit BPFE.

Richard, Goode (1984). Goverment Finance in Developing Countries. Washington.

Santiago Sanchez (2006). "On The Social Efficiency of Conflict". Endinburgh School of Economics, University of Endinburgh United Kingdom. E-mail: ssanchez@staffmail. ed.ac.uk

Sengupta, Jati. K. (2006 b). New Efficiency Theory: Extensions and New Applications of Data Emvelopment Analysis. Departement of Economics, University of California, Santa Barbara, CA 93106 USA.. Sumber Internet tanggal 2 Juni 2006

(2006 a). A Dynamic Efficiency Model Using Data Development Analysis. Departemen of Economics University of California, Santa Barbara California. E-mail sengupta@econ.ucsb.edu. Sumber Internet tanggal 2 Juni 2006.

Sharipova. E. (2001). The Efficiency And Effectiveness of Public Expenditure "Approaches To Estimating Efficiency of Public Expenditure". Working Paper Series.

Sidik, Machfud (2002). Desentralisasi Fiskal: Kebijakan, Implementasi dan Pandangan ke Depan Perimbangan Keuangan Pusat dan Daerah. Departemen Keuarigan Republik Indonesia. Data Internet 2005.

(2002). Perimbangan Keuangan Pusat dan Daerah Sebagaj Pelaksanaan Desentralisasi Fiskal: "Antara Teori dan Aplikasinya di Indonesia". Departemen Keuangan Republik Indonesia. Data internet 2005.

Sytnyk, Tetyana. (2006). Evaluating Efficiency of Lacal Public Expenditures in Ukraine. Sumber Internet - Proquest, Februari 2006.

Undang-Undang No. 32 Tahun 2004 Tentang Pemerintahan Daerah.

Undang-Undang No. 33 Tahun 2004 Tentang Perimbangan Keuangan Antara .Pemerintah Pusat Dan Daerah. 